\section{Turf Performance of Mixtures and Blends of Tall Fescue, Kentucky Bluegrass, and Perennial Ryegrass}

\author{
John H. Dunn', Erik H. Ervin'2, and Brad S. Fresenburg ${ }^{3}$ \\ Department of Horticulture, University of Missouri, Columbia, MO 65211
}

Additional index words. turfgrass, mixtures, blends, botanical composition, optical point quadrat, simulated traffic, irrigation, Festuca arundinacea, Poa pratensis, Lolium perenne

\begin{abstract}
Various mixtures of tall fescue, Festuca arundinacea Schreb., Kentucky bluegrass, Poa pratensis L., and perennial ryegrass, Lolium perenne $\mathrm{L}$., may be beneficial for turf culture because of genetic diversity and improved tolerance to environmental stresses compared with a single species. Turf-type tall fescue, dwarf tall fescue, Kentucky bluegrass, and perennial ryegrass were seeded as cultivar blends and in all possible combinations as species mixtures in two locations, irrigated and nonirrigated. Turf was mowed at 19 and $51 \mathrm{~mm}$ and subjected to an interval of brief, but intensive, simulated traffic. Perennial ryegrass was the dominant species in all mixtures with tall fescue, Kentucky bluegrass, or both. After 5 years, turf-type tall fescue comprised $62 \%$ of mixtures with Kentucky bluegrass when averaged over locations. Dwarf tall fescue comprised $48 \%$ of mixtures compared with Kentucky bluegrass at $44 \%$. Kentucky bluegrass was more competitive with tall fescue in the irrigated vs. nonirrigated location. Mowing height effected small changes in populations year to year while simulated traffic had little effect on populations at 1 year following treatment. The advantage of mixing species compared with individual species to reduce disease occurrence was evident on several occasions. Our study supports earlier research reports that tall fescue will remain competitive in mixture with Kentucky bluegrass several years after seeding.
\end{abstract}

Turfgrass mixtures provide greater genetic diversity and may give better tolerance to environmental stress than one species. For this reason, mixtures have potential for better overall quality than any one component species (Donald, 1963). However, for acceptable quality compatible species should possess similar color and vertical growth rate. One species in a mixture should not dominate another species (Beard, 1973)

Tall fescue and Kentucky bluegrass mixtures have been used extensively for athletic fields and sod production (Hall, 1977). Tall fescue has good traffic tolerance while Kentucky bluegrass rhizomes give it better recuperative capability than tall fescue following injury on athletic fields (Turgeon, 1999). For sod production, Kentucky bluegrass rhizomes are considered necessary to give sufficient strength for harvesting sod.

Limited information is available on the quality and compatibility of tall fescue and Kentucky bluegrass in mixture since improved tall fescues were first introduced in 1981 (Funk et al., 1981). According to Brede (1993), "common-type" fescues such as 'Southern Cross' are more likely to segregate into patches in mixtures with Kentucky bluegrasses than the newer turf-type (denser and finer textured) tall fescues. Hunt and Dunn (1993), working with turf-type tall fescue cultivars, reported that the

Received for publication 6 Nov. 2000. Accepted for publication 25 June 2001. Contribution from the Missouri Agricultural Experiment Station,.

${ }^{1}$ Professor. To whom reprint requests should be addressed.

${ }^{2}$ Assistant Professor.

${ }^{3}$ Research Associate. fescue component, seeded at $90 \%$ by weight of the mixture, remained competitive with Kentucky bluegrass over 5 years. Also, Brede (1993) reported that seeding mixtures of Kentucky bluegrass with $50 \%$ to $75 \%$ turf-type tall fescue by seed weight does not cause tall fescue segregation. However, mixtures with perennial ryegrass (Lolium perenne L.) may result in suppression of tall fescue because of faster seedling establishment and long term competitiveness of the ryegrass (Harkess, 1970). Hunt and Dunn (1993) reported that tall fescue established as $90 \%$ by weight of a seed mixture with perennial ryegrass comprised only $11 \%$ of the plant population after 5 years.

Turfgrass mixtures may be influenced by cultural practices such as fertilization, mowing, and irrigation (Davis, 1958). For example, withholding irrigation until all components of the mixture show drought stress would be expected to favor the more drought-tolerant grasses (Hawes, 1977). Traffic may also affect the composition of a turfgrass mixture (Youngner, 1961).

The objective of our study was to determine the practicality of maintaining tall fescue blends in compatible mixtures with blends of perennial ryegrass and Kentucky bluegrass at two cutting heights and two irrigation schedules, and subjected to an interval of short-term but intense, simulated traffic.

\section{Materials and Methods}

Cultivars of a turf-type tall fescue (TF1) blend, 'Rebel II' + 'Arid' + 'Mustang', "dwarf" (diminutive and slow growing) tall fescue (TF2) blend, 'Shortstop' + 'Trailblazer', Ken- tucky bluegrass (KB) blend, 'Baron' + 'America' + 'Merit', and perennial ryegrass (PR) blend, 'Palmer' + 'Manhattan II'+ 'Derby', were seeded as blends and in mixtures with each of the other blends. All blends consisted of equal parts by seed weight of each component cultivar. Each TF blend was seeded at a rate of $244 \mathrm{~kg} \cdot \mathrm{ha}^{-1}, \mathrm{~KB}$ at $98 \mathrm{~kg} \cdot \mathrm{ha}^{-1}, \mathrm{PR}$ at $146 \mathrm{~kg} \cdot \mathrm{ha}^{-1}$. Two-way mixtures were seeded as $244 \mathrm{TF} 1+24 \mathrm{~KB} \mathrm{~kg} \cdot \mathrm{ha}^{-1}, 244 \mathrm{TF} 1$ and 24 $\mathrm{kg} \cdot \mathrm{ha}^{-1} \mathrm{PR}, 244 \mathrm{TF} 2$ and $24 \mathrm{~kg} \cdot \mathrm{ha}^{-1} \mathrm{~KB}, 244$ TF2 and $24 \mathrm{~kg} \cdot \mathrm{ha}^{-1} \mathrm{PR}$ and $98 \mathrm{~KB}$ and 24 $\mathrm{kg} \cdot \mathrm{ha}^{-1} \mathrm{PR}$. Three way mixtures were seeded at $122 \mathrm{TF} 1,24 \mathrm{~KB}$, and $24 \mathrm{~kg} \cdot \mathrm{ha}^{-1} \mathrm{PR}$; and 122 TF2, $24 \mathrm{~KB}$, and $24 \mathrm{~kg} \cdot \mathrm{ha}^{-1} \mathrm{PR}$. TF1 and TF2 were also seeded as a composite at a rate of 122 $\mathrm{kg} \cdot \mathrm{ha}^{-1}$ of each fescue blend.

The experimental design was a randomized complete block in a split-split plot arrangement with three replications. Data were analyzed using the analysis of variance (ANOVA) procedure of SAS (SAS Institute, Cary, N.C., 1989). Irrigation represents the main plot, entry and irrigation $\times$ entry represents the subplot, and mowing and all possible interaction with the main and subplot represents the sub-sub plot. All mean comparisons in the narrative are significant at $P \leq 0.05$.

The experiment was established in Sept. 1991 on a Mexico silt loam soil (fine, montmorillonitic, mesic Mollic Endoaqualfs) in two adjacent locations. One location was irrigated as needed to prevent visual drought stress. The other location received no irrigation. Soil in the irrigated location contained $4.4 \%$ organic matter $(\mathrm{OM}), \mathrm{P} 105\left(\mathrm{~kg} \cdot \mathrm{ha}^{-1}\right), \mathrm{K}$ at 580 , and a $\mathrm{pH}$ of 6.8 . Nonirrigated soil contained 4.2\% OM, $105 \mathrm{P}, 525 \mathrm{~K}$, and $\mathrm{pH} 6.5$.

Both locations had previously been planted to a uniform stand of Kentucky bluegrass. Glyphosate [N-(phosphonomethyl) glycine] was sprayed on the bluegrass at $98 \mathrm{~kg} \cdot \mathrm{ha}^{-1}$ a.i. $\approx 30 \mathrm{~d}$ prior to seeding the blends and mixtures to kill the existing turf. One day before seeding, the dead turf was mowed to $12 \mathrm{~mm}$ and clippings and debris were removed by hand raking. Seedbeds were then prepared by verticutting (Ryan Renothin) until $\approx 50 \%$ of the surface was bare soil. A starter fertilizer $(12 \mathrm{~N}-5 \mathrm{P}-10 \mathrm{~K})$ at $30 \mathrm{~kg} \cdot \mathrm{ha}^{-1}$ was hand raked into the soil surface. The designated component cultivars of the blends and mixtures were seeded in plots $3.7 \times 4.6 \mathrm{~m}$ with a drop-type spreader calibrated to deliver each cultivar at the desired rate. The area was lightly mulched with wheat straw and then irrigated as needed to keep the soil surface moist during seedling emergence. Fertilizer was applied at a rate of $48 \mathrm{~kg} \cdot \mathrm{ha}^{-1}(20 \mathrm{~N}-4 \mathrm{P}-8 \mathrm{~K})$ in mid-October and again mid-November. Beginning in 1992 and for each year thereafter, turf was fertilized with $48 \mathrm{~kg} \cdot \mathrm{ha}^{-1}(20 \mathrm{~N}-4 \mathrm{P}-8 \mathrm{~K})$ in March, September, October, and November for an annual $\mathrm{N}$ total of $192 \mathrm{~kg} \cdot \mathrm{ha}^{-1} /$ year.

Irrigation was as needed to prevent visual drought stress in the "irrigated" location. Turf was mowed with a 3-reel (triplex) unit two times weekly at $38 \mathrm{~mm}$ during establishment. Pendimethalin [N-(1-ethylpropyl)-3,4 dimethly-2,6 dinitrobenzenamine] was applied to irrigated and nonirrigated locations at 1.68 
$\mathrm{kg} \cdot \mathrm{ha}^{-1}$ a.i. in April and May each year to prevent annual grass germination. Broadleaf weeds were controlled as needed with applications of dimethylamine salts of 2,4-D (2,4-dichlorophenoxyacetic acid) at 1.36 $\mathrm{kg} \cdot \mathrm{ha}^{-1}$ a.i. + mecoprop [(+)-2-(4 chloro-2 methylphenoxy) propanoic acid] at $0.6 \mathrm{~kg} \cdot \mathrm{ha}^{-1}$ a.i. + dicamba (3,6-dichloro-o-anisic acid) at $0.11 \mathrm{~kg} \cdot \mathrm{ha}^{-1}$ a.i.

In May 1992, we established mowing heights of $19 \mathrm{~mm}$ and $51 \mathrm{~mm}$ on one-half of each entry plot. Clippings were left on plots. Simulated traffic was applied to turf only in Oct. 1993. Turf was subjected to 15 passes on one-half of each mowed plot, three times per week for 2 weeks with a modified Brinkman traffic simulator (Cockerham et al., 1990). The simulator weighs $336 \mathrm{~kg}$ and has two heavy studded rollers that move at different speeds and compact and tear the turf. We modified the simulator to increase severity of traffic by replacing the welded nuts on the rollers with plastic football cleats, $15 \mathrm{~mm}$ long and $12.5 \mathrm{~mm}$ diameter.

Turf was evaluated once per month April to November for quality using a rating scale of 1 to 9 (best quality). We estimated severity of diseases as they occurred, using a scale of 1 (no disease) to 9 (100\% of turf affected).

An optical-point quadrat was built according to the design of Laycock and Canaway (1980) with 10 fixed optical points spaced 50 $\mathrm{mm}$ apart on a wood frame. Ten random settings of 10 fixed points were taken for a total of 100 per treatment unit. Optical point quadrat observations were made in Oct. 1994 and 1995 to estimate TF and KB composition of turf. Based upon preliminary counts, we found that PR dominated mixtures with $\mathrm{KB}, \mathrm{TF}$, or mixtures of both species, at $90 \%$ or more of the plant population and mixtures containing PR were therefore excluded from further population counts.

\section{Results and Discussion}

After five years, mixture populations averaged over the irrigated and nonirrigated locations differed according to cultivar blend and were $62 \%$ turf-type tall fescue blend (TF1) vs. $35 \%$ Kentucky bluegrass (KB) and $48 \%$ dwarf tall fescue blend (TF2) vs. 44\% Kentucky bluegrass. Occasional perennial or annual weeds comprised the remaining percentages of the turf mixtures. Previously, Turgeon and Vargas (1977) reported that Kentucky bluegrass and perennial ryegrass in mixtures differed according to cultivar blends selected for each species.

Kentucky bluegrass was more competitive with tall fescue in the irrigated location than the nonirrigated location(Fig. 1). In the nonirrigated location, the average TF population remained constant at $60 \%$ to $63 \%$ from 1994 to 1995 , but increased by $9 \%$ from $45 \%$ to $54 \%$ in the irrigated location. During the same interval, the KB population was not significantly affected by irrigation but averaged over locations decreased from $45 \%$ to $32 \%$ while the weed population increased by $\approx 10 \%$.

Earlier studies have shown that perennial

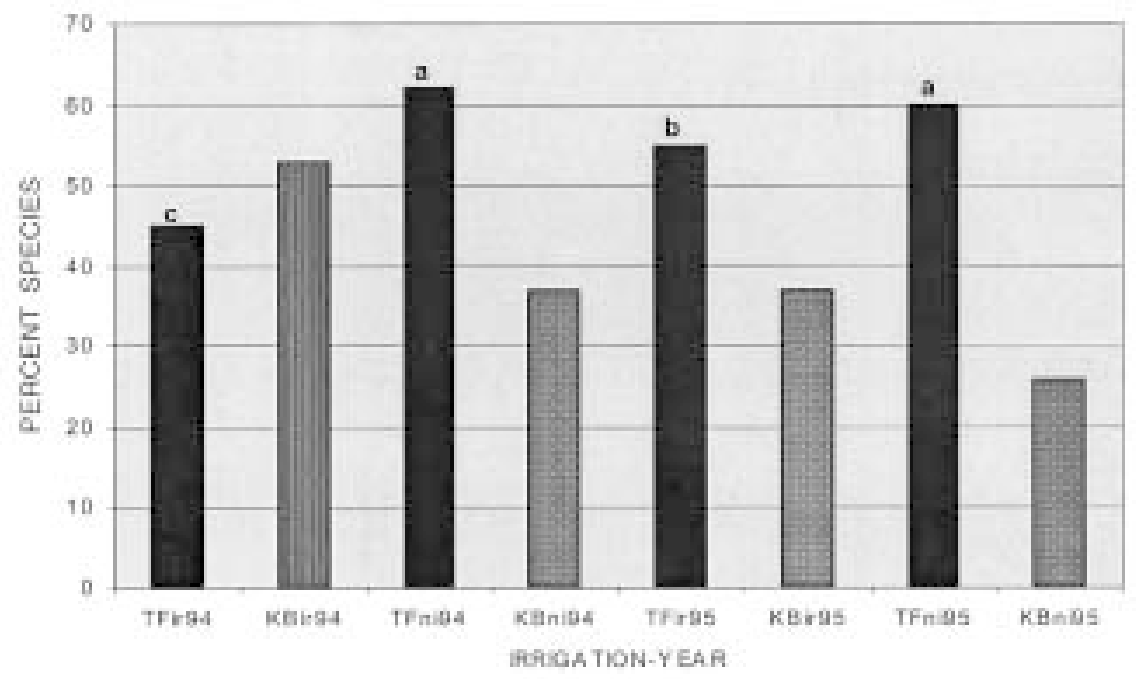

Fig. 1. Average percent turf-type and dwarf tall fescues (TF) in irrigated (ir) and nonirrigated (ni) mixtures with Kentucky bluegrass (KB) at 4 and 5 years after seeding. Letters a to $\mathrm{c}$ above TF bars indicate significant differences, $P=0.05$, for the irrigation $\times$ year interaction. There was no significant irrigation $\times$ year interaction for $\mathrm{KB}$.

Table 1. Summer quality ${ }^{2}$ of tall fescue, Kentucky bluegrass, and perennial ryegrass blends and mixtures 1991-95.

\begin{tabular}{|c|c|c|c|c|c|c|}
\hline \multirow[b]{2}{*}{ Entry $^{y}$} & \multirow[b]{2}{*}{ Irrigation $^{x}$} & \multicolumn{5}{|c|}{ Year } \\
\hline & & 1991 & 1992 & 1993 & 1994 & 1995 \\
\hline$\overline{\mathrm{TF} 1}$ & + & 4.8 & 5.4 & 4.9 & 5.7 & 5.3 \\
\hline TF2 & + & 4.8 & 5.3 & 4.8 & 5.3 & 4.8 \\
\hline $\mathrm{KB}$ & + & 5.4 & 5.1 & 5.2 & 5.3 & 4.9 \\
\hline PR & + & 4.0 & 4.4 & 4.9 & 4.9 & 5.0 \\
\hline $\mathrm{TF} 1+\mathrm{TF} 2$ & + & 4.6 & 5.0 & 4.8 & 5.1 & 5.0 \\
\hline $\mathrm{TF} 1+\mathrm{KB}$ & + & 5.4 & 5.4 & 5.5 & 5.9 & 5.4 \\
\hline $\mathrm{TF} 1+\mathrm{PR}$ & + & 4.1 & 4.5 & 4.5 & 4.7 & 4.9 \\
\hline $\mathrm{TF} 2+\mathrm{KB}$ & + & 5.1 & 5.2 & 5.6 & 6.0 & 5.5 \\
\hline $\mathrm{TF} 2+\mathrm{PR}$ & + & 4.1 & 4.5 & 4.8 & 4.6 & 5.0 \\
\hline $\mathrm{KB}+\mathrm{PR}$ & + & 4.6 & 4.7 & 4.9 & 5.4 & 4.8 \\
\hline $\mathrm{TF} 1+\mathrm{KB}+\mathrm{PR}$ & + & 4.8 & 4.7 & 4.9 & 5.0 & 5.3 \\
\hline $\mathrm{TF} 2+\mathrm{KB}+\mathrm{PR}$ & + & 4.6 & 4.7 & 5.0 & 5.2 & 5.0 \\
\hline TF1 & - & 5.1 & 4.8 & 4.6 & 4.9 & 4.8 \\
\hline TF2 & - & 4.8 & 4.7 & 4.4 & 4.3 & 3.7 \\
\hline $\mathrm{KB}$ & - & 4.4 & 3.7 & 4.9 & 3.8 & 4.2 \\
\hline PR & - & 3.2 & 4.0 & 4.4 & 4.5 & 4.8 \\
\hline $\mathrm{TF} 1+\mathrm{TF} 2$ & - & 5.0 & 4.7 & 5.1 & 5.1 & 5.0 \\
\hline $\mathrm{TF} 1+\mathrm{KB}$ & - & 5.1 & 4.6 & 5.3 & 5.5 & 5.1 \\
\hline $\mathrm{TF} 1+\mathrm{PR}$ & - & 3.8 & 4.2 & 4.4 & 4.5 & 4.7 \\
\hline $\mathrm{TF} 2+\mathrm{KB}$ & - & 5.0 & 4.6 & 5.3 & 5.1 & 4.8 \\
\hline $\mathrm{TF} 2+\mathrm{PR}$ & - & 3.8 & 4.0 & 4.4 & 4.6 & 4.5 \\
\hline $\mathrm{KB}+\mathrm{PR}$ & - & 3.3 & 4.0 & 4.6 & 4.6 & 4.7 \\
\hline $\mathrm{TF} 1+\mathrm{KB}+\mathrm{PR}$ & - & 4.0 & 4.5 & 4.9 & 4.8 & 4.8 \\
\hline $\mathrm{TF} 2+\mathrm{KB}+\mathrm{PR}$ & - & 3.7 & 4.1 & 4.6 & 4.5 & 4.7 \\
\hline $\operatorname{LSD}_{0.05}{ }^{\mathrm{w}}$ & & 0.5 & 0.4 & 0.3 & 0.3 & 0.3 \\
\hline Source of variation & df & & & & & \\
\hline Irr & 1 & $* *$ & ** & NS & $* *$ & $*$ \\
\hline Rep (Irr) & 4 & 0.2277 & 0.1799 & 0.2808 & 0.2721 & 0.6558 \\
\hline Entry & 11 & ** & ** & ** & ** & $* *$ \\
\hline Irr $\times$ Entry & 11 & $* *$ & $*$ & * & $* *$ & NS \\
\hline Rep (Irr × Entry) & 44 & 0.1207 & 0.1227 & 0.1509 & 0.0717 & 0.2326 \\
\hline Mow & 1 & ** & ** & ** & ** & NS \\
\hline Irr $\times$ Mow & 1 & NS & NS & NS & ** & NS \\
\hline Mow $\times$ Entry & 11 & * & NS & $* *$ & NS & * \\
\hline Irr $\times$ Mow $\times$ Entry & 11 & NS & NS & NS & NS & NS \\
\hline Error $\mathrm{C}$ & 48 & 0.0406 & 0.0498 & 0.0515 & 0.0570 & 0.0824 \\
\hline
\end{tabular}

${ }^{2}$ Scale: 1 (dead turf) to 9 (highest quality). Values represent averages of monthly ratings Jun, Jul, Aug, Sept. ${ }^{\mathrm{y} T F} 1$ = Tall fescue turf-type blend of cultivars Rebel II + Arid + Mustang; TF2 = tall fescue dwarf blend of cultivars Shortstop + Trailblazer; KB = Kentucky bluegrass blend of cultivars Baron + America + Merit; PR = perennial ryegrass blend of cultivars Palmer + Manhattan II + Derby .

${ }^{x_{+}}=$irrigated; $-=$nonirrigated.

"For comparison of entries within an irrigation regime or a single entry between irrigation regimes.

${ }^{*}, * *$ Significant at $P \geq 0.05,0.01$, respectively. 
ryegrass $(\mathrm{PR})$ in mixtures may dominate $\mathrm{TF}$ and $\mathrm{KB}$ regardless of management. Based upon two years of observations, Brede and Duich (1984b) suggested that a KB + PR seed mixture should contain $\approx 50 \%$ to $85 \% \mathrm{~KB}$ for adequate $\mathrm{KB}$ establishment. However, our study indicates that a $\mathrm{KB}+\mathrm{PR}$ seeding mixture containing only $10 \%$ PR by seed weight will eventually be dominated by PR. This finding supports the earlier research of Hunt \& Dunn ( 1993) who reported that all mixture combinations of TF and KB containing PR were dominated by PR after 5 years. Likewise, Hsiang et al (1997) reported that a seeding mixture of $90 \% \mathrm{~KB}$ to $10 \%$ PR by seed weight was dominated by PR after 4 years. Reports by Brede and Duich (1984a) and Hall (1977) showed that mowing had an early effect on the balance of TF and KB in mixture. Our research indicates that mowing may effect small year to year changes in mixture populations. In our study, TF mowed at $19 \mathrm{~mm}$ increased slightly from $53 \%$ to $59 \%$ from 1994 to 1995 while KB decreased from $46 \%$ to $29 \%$. However, at the $51 \mathrm{~mm}$ cutting height, TF was unchanged 1994 to 1995 at $55 \%$ while the KB population decreased from $43 \%$ to $34 \%$. The TF1 blend was somewhat more competitive at $19 \mathrm{~mm}$ (65\%) than $51 \mathrm{~mm}(60 \%)$, compared with $47 \%$ at $19 \mathrm{~mm}$ and $51 \%$ at $51 \mathrm{~mm}$ for the TF2 blend. Weeds increased from an average 2\% in 1994 to $12 \%$ of the population in 1995 , but were unaffected by mowing height.

The Kentucky bluegrass blend and some mixtures containing KB showed more rapid recovery than the tall fescue blend at eight weeks following simulated traffic. However, all entries were in poor condition at this time with maximum quality averaged over locations of only 2.5 ( 9 = best quality). The harmful effect of traffic on blends and mixtures was still apparent in May, 1994, $\approx 7$ months after traffic was imposed on turf, with average nontrafficked turf quality of 6.4 vs. 5.3 for trafficked turf. However, there were no significant differences among mixtures and blends at this time. By mid-June, the influence of traffic was no longer visible, 5.6 nontrafficked vs. 5.4 trafficked. Population counts 1 year after traffic showed that trafficked KB decreased from $39 \%$ to $36 \%$ of mixture compared with nontrafficked turf at the $19-\mathrm{mm}$ cutting height and increased from $36 \%$ to $41 \%$ at the 51-mm cutting height. Otherwise, there was no prolonged effect of intense, short term traffic.

Summer quality (June-Sept.) of irrigated plots was generally better than that of nonirrigated plots for the duration of the study, 1991-95. However, there were significant interactions as nonirrigated turf quality occasionally equaled or exceeded that of irrigated turf (Table 1). The main effect for irrigation was nonsignificant only in 1993 when turf received above normal rainfall May through September (Fig. 2). Mixtures sometimes gave better quality than either species as blends. For example, $\mathrm{TF}+\mathrm{KB}$ often gave superior quality compared with the TF blend and, especially, the KB blend, over the 5-year period. This response may be attributed on occasion to

Monthly Precipitation for South Farms (1991-1995)

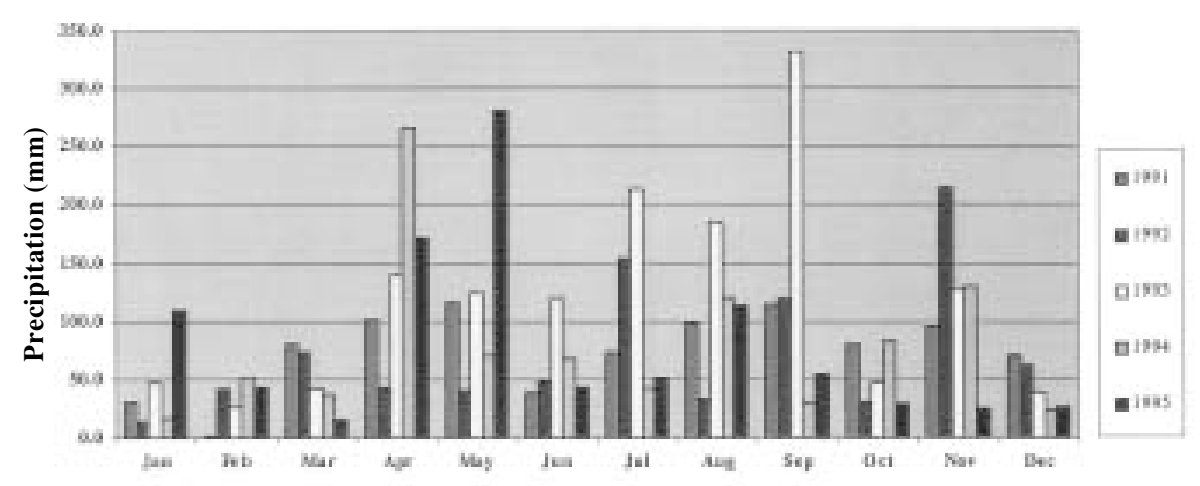

Average Monthly Temperature for South Farms (1991-1995)

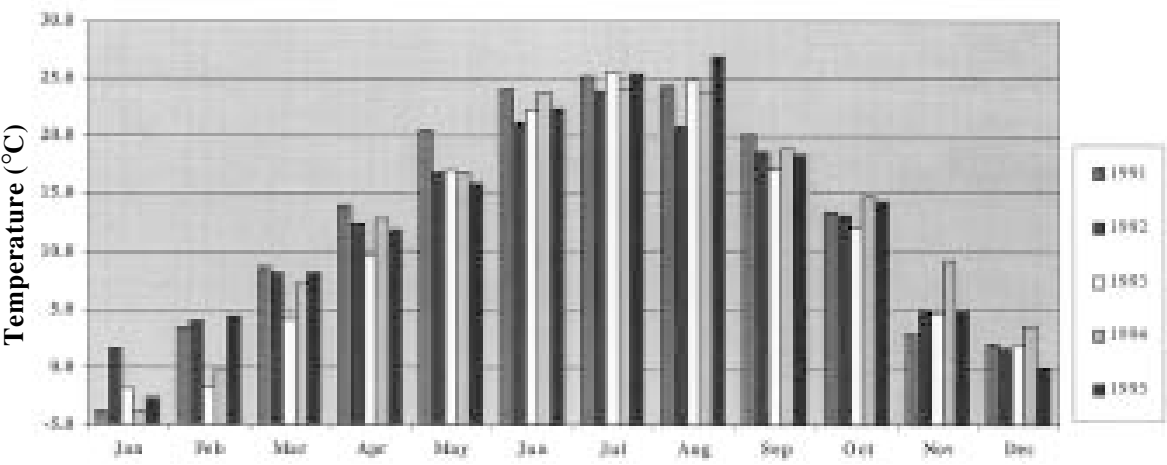

Fig. 2. Average monthly precipitation and temperatures, 1991-95, Univ. of Missouri South Farms Turfgrass Research Center, Columbia, Mo.

better disease resistance of the mixture compared with individual components.

When mowing effect was significant (Table 1), quality of entries improved with higher mowing. The mowing $\times$ entry interaction on quality was significant (Table 1) in 1991, 93, and 95. For example, in 1991, TF2 + PR quality was better at $51 \mathrm{~mm}$ compared with 19 mm while TF2 + KB quality was unaffected by mowing height (data not shown).

The advantage of mixing species was evident in May 1991 when dollar spot caused by Sclerotinia homeocarpa F.T. Bennett was rated. The PR + KB mixture had less dollar spot, 2.5 rating, than the PR blend, 5.3 rating (Table 2). Dollar spot was the most prevalent disease during the 5-year study and mostly affected PR with little occurrence in KB. Presumably, $\mathrm{PR}$ and $\mathrm{KB}$ populations were more balanced in mixture in 1991 compared with 1994 , so that the positive influence of KB on less dollar spot in the mixture would be more apparent early in the study. Although no population counts were made in 1991, Hunt and Dunn (1993) reported that a mixture of TF and PR was evenly balanced early in their study at $45 \%$ of each species 2 years after seeding. Three years after seeding in the present study, when PR dominated mixtures, the advantage of mixing species was still apparent, but dollar spot became more evident in the mixture as the competitive influence of Kentucky bluegrass and tall fescue declined. At this time, $\mathrm{PR}$ received a disease rating of 5.3 vs. 2.7 for TF2 + KB + PR (Table 2).

Infestations of brown patch caused by Rhizoctonia solani Kuhn were observed mostly in TF and occasionally PR, but were often less evident in mixtures compared with species blends (Table 3). Irrigation sometimes influenced disease but this effect was dependent on species affected. For example, in 1994, PR dominated plots were heavily infested with dollar spot and irrigated plots were most severely affected (average 4.3 vs. 2.8 for nonirrigated). However, brown patch in 1992 was more apparent in nonirrigated plots, perhaps because TF turf took longer to recover from disease injury in that location compared with irrigated turf. The interaction for entry $x$ mowing on Rhizoctonia incidence was significant in July, 1992 (Table 3). TF1 + TF2, $\mathrm{PR}$, and mixtures containing PR had greater disease infestation at $51 \mathrm{~mm}$ while TF1 + TF2 and $\mathrm{TF}+\mathrm{KB}$ mixtures were unaffected by mowing height (data not shown).

Previously, Hunt and Dunn (1993) reported that a mixture of tall fescue and Kentucky bluegrass appeared to stabilize after 4 years. However, results of our study suggest that 
Table 2. Dollar spot $^{\mathrm{z}}$ in blends and mixtures.

\begin{tabular}{|c|c|c|c|}
\hline \multirow[b]{2}{*}{ Entry $^{y}$} & & \multicolumn{2}{|c|}{ Disease rating } \\
\hline & & May 1991 & July 1992 \\
\hline $\mathrm{KB}+\mathrm{PR}$ & & 2.5 & 4.2 \\
\hline PR & & 5.3 & 4.2 \\
\hline $\mathrm{TF} 2+\mathrm{PR}$ & & 4.3 & 4.2 \\
\hline $\mathrm{TF} 2+\mathrm{KB}+\mathrm{PR}$ & & 2.3 & 3.8 \\
\hline KB & & 1.0 & 3.2 \\
\hline $\mathrm{TF} 1+\mathrm{KB}+\mathrm{PR}$ & & 2.7 & 3.1 \\
\hline $\mathrm{TF} 1+\mathrm{PR}$ & & 3.2 & 3.0 \\
\hline TF2 & & 1.0 & 1.5 \\
\hline TF1 & & 1.2 & 1.3 \\
\hline $\mathrm{TF} 2+\mathrm{KB}$ & & 1.2 & 1.3 \\
\hline $\mathrm{TF} 1+\mathrm{KB}$ & & 1.1 & 1.2 \\
\hline $\mathrm{TF} 1+\mathrm{TF} 2$ & & 1.0 & 1.1 \\
\hline $\operatorname{LSD}_{0.05}$ & & 0.8 & 1.1 \\
\hline Source of variation & df & & \\
\hline$\overline{\mathrm{Irr}}$ & $\overline{1}$ & NS & NS \\
\hline Reg (Irr) & 4 & 4.4097 & 3.2569 \\
\hline Entry & 11 & $* *$ & $* *$ \\
\hline Irr $\times$ Entry & 11 & NS & NS \\
\hline Rep (Irr × Entry) & 44 & 1.1370 & 1.5221 \\
\hline Mow & 1 & NS & $* *$ \\
\hline Irr $\times$ Mow & 1 & $*$ & NS \\
\hline Mow $\times$ Entry & 11 & NS & NS \\
\hline Irr $\times$ Mow $\times$ Entry & 11 & NS & NS \\
\hline Error C & 48 & 0.1736 & 0.5000 \\
\hline \multicolumn{4}{|c|}{ 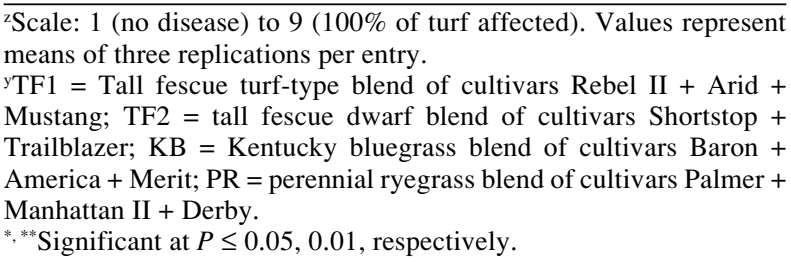 } \\
\hline
\end{tabular}

Table 3. Brown patch ${ }^{z}$ in blends and mixtures.

\begin{tabular}{|c|c|c|c|}
\hline \multirow[b]{2}{*}{ Entry $^{y}$} & & \multicolumn{2}{|c|}{ Disease rating } \\
\hline & & July 1992 & July 1993 \\
\hline TF2 & & 2.7 & 4.6 \\
\hline $\mathrm{TF} 1+\mathrm{PR}$ & & 1.7 & 4.5 \\
\hline TF1 & & 2.3 & 4.3 \\
\hline $\mathrm{TF} 2+\mathrm{PR}$ & & 1.0 & 3.9 \\
\hline $\mathrm{TF} 1+\mathrm{TF} 2$ & & 2.6 & 3.8 \\
\hline PR & & 1.0 & 3.3 \\
\hline $\mathrm{KB}+\mathrm{PR}$ & & 1.0 & 3.3 \\
\hline $\mathrm{TF} 2+\mathrm{KB}+\mathrm{PR}$ & & 1.3 & 3.1 \\
\hline $\mathrm{TF} 1+\mathrm{KB}+\mathrm{PR}$ & & 1.3 & 3.0 \\
\hline $\mathrm{TF} 1+\mathrm{KB}$ & & 2.1 & 2.6 \\
\hline $\mathrm{TF} 2+\mathrm{KB}$ & & 2.3 & 2.3 \\
\hline $\mathrm{KB}$ & & 1.0 & 1.7 \\
\hline $\mathrm{LSD}_{0.05}$ & & 1.0 & 1.1 \\
\hline Source of variation & df & & \\
\hline$\overline{\mathrm{Irr}}$ & $\overline{1}$ & NS & $*$ \\
\hline Rep (Irr) & 4 & 0.9028 & 1.7083 \\
\hline Entry & 11 & $* *$ & $* *$ \\
\hline Irr $\times$ Entry & 11 & NS & NS \\
\hline Rep (Irr × Entry) & 44 & 1.2285 & 1.2462 \\
\hline Mow & 1 & NS & $* *$ \\
\hline Irr $\times$ Mow & 1 & NS & NS \\
\hline Mow $\times$ Entry & 11 & NS & $*$ \\
\hline Irr $\times$ Mow $\times$ Entry & 11 & NS & NS \\
\hline Error C & 48 & 0.3403 & 0.5069 \\
\hline
\end{tabular}

${ }^{\mathrm{z}}$ Scale: 1 (no disease) to 9 (100\% of turf affected). Values represent means of three replications per entry.

yTF1 $=$ Tall fescue turf-type blend of cultivars Rebel II + Arid + Mustang; $\mathrm{TF} 2$ = tall fescue dwarf blend of cultivars Shortstop + Trailblazer; KB = Kentucky bluegrass blend of cultivars Baron + America + Merit; PR = perennial ryegrass blend of cultivars Palmer + Manhattan II + Derby. ${ }^{*}$, ** Significant at $P \leq 0.05,0.01$, respectively. environmental factors such as rainfall could account for significant annual population swings beyond 4 years. For example, in May 1995 , rainfall of $281 \mathrm{~mm}$ (Fig. 2), $30 \%$ of the annual total for that year, may have hastened degradation of an April pre-emergence application of pendimethalin and speeded crabgrass development. The result was $\approx 10 \%$ increase in crabgrass by fall, and a similar decrease in percent Kentucky bluegrass as a component of the mixtures.

In summary, our results support earlier reports by Hunt and Dunn (1993) and Hsiang et al. (1997) that TF as a high percentage of the seeding mixture will remain competitive after several years with $\mathrm{KB}$ in established turf. PR as a low percentage of the seeding mixture will eventually dominate both TF and KB in mixtures regardless of management. Disease influenced turfgrass quality and, on occasion, the advantage of mixing species for disease resistance was apparent.

\section{Literature Cited}

Beard, J.B. 1973. Turfgrass: Science and culture. Prentice Hall, Engelwood Cliffs, N.J.

Brede, A.D. 1993. Tall fescue/Kentucky bluegrass mixtures: Effect of seeding rate, ratio, and cultivar on establishment characteristics, p. 1005A-
1005G. In: R.N. Carrow, N.E. Christians, and R.C. Shearman (eds.). Intl. Turfgrass Soc. Res. J. Vol. 7. Intertec Pub., Overland Park, Kans.

Brede, A.D. and J.H. Duich. 1984a. Initial mowing of Kentucky bluegrass-perennial ryegrass seedling turf mixtures. Agron. J. 76:711-714.

Brede, A.D. and J.H. Duich. 1984b. Establishment characteristics of Kentucky bluegrass-Perennial ryegrass turf mixtures as affected by seeding rate and ratio. Agron. J. 76:875-879.

Cockerham, S.T., Gibeault, V.A., Van Dam, J., and M.K. Leonard. 1990. Tolerance of several coolseason turfgrasses to simulated sports traffic, $\mathrm{p}$. 85-95. In: R.C. Schmidt et al. (eds.). Natural and artificial playing fields: Characteristics and safety features. Proc. Symp. Characteristics and Safety of Playing Surfaces (Artificial and Natural) for Field Sports, Phoenix, 6 Dec. 1988. ASTM, Philadelphia.

Davis, R.R. 1958. The effect of other species and mowing height on the persistence of lawn grasses. Agron. J. 50:671-673.

Donald, C.M. 1963. Competition among crop and pasture plants. Adv. Agron. 15:1-118.

Funk, C.R., Engel, R.E., Dickson, W.K., and R.H. Hurley. 1981. Registration of 'Rebel' tall fescue. Crop Sci. 21:632.

Hall, J.R. 1977. Effect of cultural factors on tall fescue-Kentucky bluegrass sod quality and botanical composition, p. 367-377. In: J.B. Beard (ed.). Proc. of the 3rd Intl. Turfgrass Res. Conf., Munich, Germany. Amer. Soc. Agron., Madison, Wisc.
Harkess, R.D. 1970. Competition between tall fescue and perennial ryegrass in pure and mixed swards under simulated field condition. J. Appl. Ecol. 7:497-506.

Hawes, D.T. 1977. Response of warm and cool season turfgrass polystands to nitrogen and topdressing. p. 65-74. In: J.B. Beard (ed.) Proc. of the 3rd Intl. Turfgrass Res. Conf., Munich, Germany. Amer. Soc. Agron., Madison, Wisc.

Hsiang, T., Carey, K., He, B., and J.E. Eggens. 1997. Composition of mixtures of four turfgrass species four years after seeding under non-wear conditions. Intl. Turfgrass Soc. Res. J. 8:671679.

Hunt, K.L. and J.H. Dunn. 1993. Compatibility of Kentucky bluegrass and perennial ryegrass with tall fescue in transition zone turfgrass mixtures. Agron. J. 85:211-215.

Laycock, R.W., and P.M. Canaway. 1980. A new optical point quadrat frame for the estimation of cover in close mowed turf. J. Sports Turf Inst. 56:91-92.

SAS Institute. 1989. SAS user's guide: Statistics. Version 6 ed. SAS Inst., Cary, N.C.

Turgeon, A.J., and J. M. Vargas. 1977. An approach to turfgrass cultivar evaluation, p. 19-30. In: J. B. Beard (ed.). Proc. of the 3rd Intl. Turfgrass Res. Conf., Munich, Germany. Amer. Soc. Agron., Madison, Wisc.

Turgeon, A.J. 1999. Turfgrass management. Prentice Hall. Upper Saddle River, N.J.

Youngner, V.B. 1961. Accelerated wear tests on turfgrasses. Agron. J. 53:217-218. 